\title{
Pathogenicity of Ganoderma Species on Landscape Trees in the Southeastern United States
}

Andrew L. Loyd, ${ }^{\dagger}$ Eric R. Linder, and Nicolas A. Anger, University of Florida, School of Forest Resources and Conservation, Gainesville, FL 32611; Brantlee S. Richter, University of Florida, Plant Pathology Department, Gainesville, FL 32611; Robert A. Blanchette, University of Minnesota, Department of Plant Pathology, St. Paul, MN 55108; and Jason A. Smith, University of Florida, School of Forest Resources and Conservation, Gainesville, FL 32611

\begin{abstract}
The genus Ganoderma contains species that are associated with dead and declining host trees. Many species have been described as pathogens in literature, because anecdotally, the presence of fruiting bodies on living trees has been widely associated with a general decline in tree health. Few studies have investigated the pathogenicity of Ganoderma species on landscape trees in the southeastern U.S. Pathogenicity tests were used to determine the pathogenicity of G. curtisii, G. meredithiae, G. sessile, and G. zonatum on young, healthy landscape trees (Pinus elliottii var. elliottii, P. taeda, Quercus shumardii, Q. virginiana, and Butia odorata) common to the southeastern U.S. Inoculations were made by drilling into the sapwood of the lower bole and inserting wooden dowels that were infested with each Ganoderma species. In two field experiments, 11 to 12 months post inoculation, trees had no visual, external symptoms of disease. There were differences in the extent of internal xylem discoloration near the site of inoculation in comparison with the

mock-inoculated control in experiment 1 , but there were no differences relative to the control in experiment 2. In both experiments, $G$. sessile was the only species that was successfully reisolated from the pine and oak hosts. Although disease symptoms were not obvious, the reisolation of $G$. sessile outside the inoculation point was a significant finding, and suggests that this species was capable of infecting healthy sapwood. G. sessile constitutively produces chlamydospores within its vegetative mycelium, which may contribute to its persistence in the discolored sapwood. These data suggest that the Ganoderma species tested, following trunk wounding, are not pathogens of young, actively growing landscape trees that only possess sapwood. The establishment of these fungi using alternative infection courts (e.g., roots) and their interactions in older living trees (e.g., trees with heartwood) needs investigation to better understand their effects on tree health.
\end{abstract}

Ganoderma is a large, diverse, globally distributed genus of the Basidiomycota that contains species that cause a white rot on a variety of tree species. The taxonomy of the laccate (varnished or polished) Ganoderma species is confusing, and for the past century, a majority of authors that have reported findings on Ganoderma in the United States have used the name G. lucidum sensu lato for any laccate Ganoderma species growing on hardwood trees (Adaskaveg and Gilbertson 1987; Gilbertson and Ryvarden 1986; Pirone 1957; Zhou et al. 2015). It is now known through phylogenetic studies that G. lucidum sensu stricto (Curtis) Karst is native to Europe and parts of China (Hennicke et al. 2016; Zhou et al. 2015), but not North America. In North America, the G. lucidum sensu lato species complex consists of many species that are currently being elucidated using molecular phylogenetic methods (Hong and Jung 2004; Moncalvo et al. 1995; Wang et al. 2012; Zhou et al. 2015). Due to these taxonomic revisions, studies that have focused on the ecology and general biology of Ganoderma species in North America need to be reevaluated. It is currently unclear which Ganoderma species were examined in many earlier studies, and whether conclusions drawn from studies on $G$. lucidum sensu lato can be applied across all Ganoderma species formerly included under this name.

White rot fungi, including species of Ganoderma, possess enzymes that break down cellulose, hemiceullulose, and lignin, the major structural components of wood (Schwarze et al. 2000). Species of Ganoderma are capable of both simultaneous decay, the process where cellulose and lignin are gradually decayed over time, and

${ }^{\dagger}$ Corresponding author: A. L. Loyd; E-mail: aloyd@bartlett.com

Funding: The authors are grateful to The F.A. Bartlett Tree Experts Company and the International Society of Arboriculture, Florida Chapter for funding this research.

Accepted for publication 7 April 2018.

C) 2018 The American Phytopathological Society selective delignification, where lignin is preferentially decayed over cellulose (Blanchette 1984). Previous studies have suggested that trees with simultaneous decay have more wood strength loss and are more concerning for tree safety compared with trees where fungi have caused selective delignification (Schwarze and Ferner 2003). While Ganoderma species can be found on living trees, infected trees often die due to windthrow or breaks caused by a loss of strength and rigidity due to decay of the cellulose and lignin of the lower bole or root flare (Sinclair and Lyon 2005). Because of this, when Ganoderma fruiting bodies are found on living trees, these trees are often deemed hazardous and removed, preemptively, without doing other advanced assessments of decay such as sounding, resistance drilling, and sonic tomography etc.

Numerous studies have reported Ganoderma as a causal agent of disease, associated with death and a general decline, in various tree species (Adaskaveg et al. 1991, 1993; Bhadra 2015; Coetzee et al. 2015; Elshafie et al. 2013; Fernando 2008; Glen et al. 2009; Mahmood 1970; Toole 1966), while fewer studies have successfully completed Koch's postulates to prove the causality of Ganoderma in tree decline (Adaskaveg and Gilbertson 1987; Deflorio et al. 2008; Elliott and Broschat 2001; Hidayati et al. 2014; Nicolotti et al. 2004; Pirone 1957; Toole 1966). For example, Nicolotti et al. (2004) performed pathogenicity tests with $G$. adspersum on young linden (Tilia sp.) and horse-chestnut (Aesculus sp.) in Italy, where G. adspersum was inoculated into drilled holes in the lower bole. Two years postinoculation, decay columns were observed originating from the inoculation sites on all trees inoculated with this method, and the pathogen was reisolated or confirmed with a molecular method. Similarly, in New York, Pirone (1957) conducted pathogenicity tests where infested agar plugs or pieces of fruiting body tissue of G. lucidum sensu lato were placed into holes drilled into lower trunk tissue of young Acer platanoides (Norway maple), and in both cases, infection occurred and symptoms were observed. On the contrary, although $G$. zonatum is considered a destructive palm pathogen (Elliott and Broschat 2001), no infections or disease were observed when palms were inoculated with G. zonatum in Florida, despite the authors using several different inoculation methods. 
The current paradigm of the disease life cycle of Ganoderma butt and root rot of living trees is that basidiospores (primary inoculum) initiate infections in wounds of roots of the lower boles of trees (infection courts) and cause decay, which leads to a general decline in tree health (Sinclair and Lyon 2005). Recent surveys of basidiomycete endophytes in trees have revealed that wood decay fungi, including Ganoderma species, can be found in sound wood of living trees presumably living as endophytes, which adds another putative step to the general life cycle of this potential root and butt rot pathogen (Martin et al. 2015; Parfitt et al. 2010; Song et al. 2017). Infection and establishment of a given Ganoderma species on a particular host appears to be somewhat host-group specific, wherein specific Ganoderma species are found predominately on certain groups of hosts (i.e., conifers, hardwoods, or palms) (Gilbertson and Ryvarden 1986). For example, G. zonatum is associated with palms, G. meredithiae is associated with pines, and $G$. curtisii is associated with hardwoods (Adaskaveg and Gilbertson 1988; Elliott and Broschat 2000; Gilbertson and Ryvarden 1986).

Tree species have evolved mechanisms of chemical and physical resistance to pathogenic decay organisms in living sapwood (Adaskaveg et al. 1991; Baietto and Wilson 2010; Scheffer and Cowling 1966). Living trees can actively compartmentalize infections and wounds. Active compartmentalization can vary among tree species and within individual tree species across different environmental conditions (Boddy and Rayner 1983; Shigo and Hillis 1973). Furthermore, trees respond to wounds or infections in sapwood by producing antimicrobial chemicals such as resins, tannins, and phenols, which impede the growth of many pathogenic decay fungi (Scheffer and Cowling 1966). For example, pines produce resins and antimicrobial chemicals such as pinosylvins and monomethyl ethers, following wounding, fungal infection, insect attack, or desiccation of wood (Jorgensen 1961). Similarly, oak trees produce phenolic compounds in sapwood following colonization by fungi or insects or wounding of cambium, and there are differences in decay resistance across different oak species (Deflorio et al. 2008; Scheffer and Morrell 1998; Shigo 1985). In addition to pure chemistry defense tactics, defense to bark beetles and infectious fungi in trees is dynamic and progressive, where the defense strategy involves repellency, defending and killing the foreign agents, and finally compartmentalization if the invading agent is tolerant of initial defenses (Franceschi et al. 2005).

Before sapwood dies and is converted to heartwood, which consists of mostly dead cells, antimicrobial chemicals are impregnated into these cells, usually staining the wood a darker color (Schwarze et al. 2000). In many types of trees the heartwood is chemically more resistant than sapwood due to deposited extractives (e.g., phenolic compounds), which are the primary defense against decay in these tissues (Schwarze et al. 2000). In a study focusing on decay in living sapwood of trees, true heartwood-forming species such as oak and Douglas-fir had a higher concentration of phenolic compounds and were more decay resistant after wound inoculation, relative to beech and sycamore (Deflorio et al. 2008). Sapwood of conifers is on average more resistant to decay relative to sapwood of hardwood trees (Baietto and Wilson 2010). Host specialization of Ganoderma species could be due to the coevolution of the fungus and host, where Ganoderma species have evolved to overcome the plant defenses of its host, and tree species have evolved more efficient defense mechanisms.

Given the previous ambiguity in taxonomy of the North American Ganoderma species, and the lack of pathogenicity data for
Ganoderma species found in the southeastern U.S., research is needed to determine the pathogenicity of these fungi in commonly used landscape trees, where "pathogenicity" is defined as the ability of an organism to cause disease, and "disease" is defined as any negative change to host cell or tissue as a result of continuous perturbation by a pathogen that results in symptom development (Agrios 2005). Knowledge of differences in pathogenicity among Ganoderma species on actively growing trees with only sapwood will aid in interpretations of diagnosed infections. The major objective of this study is to investigate the pathogenicity of four Ganoderma taxa native to the southeastern U.S. on healthy, actively growing oak (Quercus shumardii and Q. virginiana), pine (Pinus elliottii and $P$. taeda), and palm (Butia odorata) trees, which are tree species that coexist as common in landscape plantings in the southeastern United States.

\section{Materials and Methods}

Ganoderma isolates. The Ganoderma species G. curtisii, G. meredithiae, G. sessile, and G. zonatum were commonly observed taxa in a survey (2016-2018) of Ganoderma from the southeastern United States across a variety of hosts (data not published). Isolations were made from basidiocarps of each species by taking small pieces $\left(<1 \mathrm{~mm}^{3}\right)$ of context tissue with a sterile scalpel and placing them onto malt extract agar media (MEA, Difco Laboratories, Franklin Lakes, NJ) prepared according to the manufacturer's recipe with the addition of streptomycin (100 mg/liter) (Fisher Scientific, Waltham, MA), benomyl 95\% (4 mg/liter) (Fisher Scientific, Waltham, MA), and lactic acid 95\% (1 ml/liter) (Fisher Scientific, Waltham, MA). One isolate of each species was used for this study. Cultures were maintained on MEA slants as working stocks prior to use, and infested agar discs were submerged in sterile water for long term storage (Marx and Daniel 1976). Samples were initially identified based on the macro- and micromorphological features of basidiocarps, and these identifications were validated through sequencing the internal transcribed spacer (ITS) region of the ribosomal DNA (rDNA). DNA was extracted from mycelium of each isolate with the Extract-N-Amp rapid DNA kit (Sigma-Aldrich, St. Louis, MO) according to the manufacturer's instructions. Amplification of the ITS region was performed with the primers ITS1f and ITS4 on a MJ Mini thermocycler (BioRad, Hercules, CA) with an initial cycle of $94^{\circ} \mathrm{C}$ for $4 \mathrm{~min}$ followed by 37 cycles of $94^{\circ} \mathrm{C}$ for $50 \mathrm{~s}, 55^{\circ} \mathrm{C}$ for 50 $\mathrm{s}$, and $72^{\circ} \mathrm{C}$ for $1 \mathrm{~min}$, that produced an amplicon of $\sim 700$ to 800 nucleotides in length (Gardes and Bruns 1993; White et al. 1990). Amplicons were purified with Exo-SAP-IT (ThermoFisher, Waltham, MA) according to the manufacturer's instructions. Sanger sequencing was performed using both forward and reverse primers at the Interdisciplinary Center for Biotechnology Research (ICBR) at the University of Florida. Sequences were edited and aligned using Sequencher v. 5.3 (Gene Codes, Ann Arbor, MI). ITS sequences generated here were deposited and accessioned in the GenBank sequence database (Table 1)

Host plants. For each repetition of the pathogenicity tests, 25 large containerized (57 or 114 liter) live oak ( $Q$. virginiana), loblolly pine (P. taeda-experiment 1), or slash pine ( $P$. elliottii var. elliottii-experiment 2), Pindo palm (B. odorata), and Shumard oak ( $Q$. shumardii) were sourced from commercial growers in North Florida. These tree species were selected based on the following criteria: i) commonly planted landscape plants in the southeastern U.S., and ii) trees were known hosts for at least one of the four Ganoderma taxa. Individual trees within a species were of similar size; where live oaks were

Table 1. List of Ganoderma spp. isolates used in this study with associated GenBank accession, location of collection, and host information from collection if available

\begin{tabular}{|c|c|c|c|c|}
\hline Isolate & Taxon & Host type & Location & ITS GenBank accession \\
\hline UMNFL60 & G. curtisii & Unknown hardwood & Florida & KY767033 \\
\hline UMNFL64 & G. meredithiae & Pinus elliottii & Florida & KY646220 \\
\hline UMNFL10 & G. sessile & Unknown hardwood & Florida & KY708884 \\
\hline UMNFL85 & G. zonatum & Serenoa repens & Florida & KY646212 \\
\hline
\end{tabular}


approximately 2.5 to $3.8 \mathrm{~cm}$ in diameter, Shumard oaks were approximately $5.1 \mathrm{~cm}$ in diameter and pines were approximately 5.1 (experiment 1) and $7.6 \mathrm{~cm}$ (experiment 2) in diameter. Pindo palms had no evident pseudobark, and were still in a grass like stage.

Experimental setup and inoculations. For each repetition, the pathogenicity tests were set up in a randomized complete design with a full factorial arrangement, with one isolate of each of the four Ganoderma species plus a mock inoculated control across four tree species with five replicates per Ganoderma-host combination $(n=$ 100). The experiment was staged outdoors on container pads in Gainesville, FL, and the experiment was repeated once with inoculations in the summer (experiment 1) and winter (experiment 2). The average temperatures in Gainesville during the two months postinoculation (establishment phase) was $28.3^{\circ} \mathrm{C}$ (experiment 1) and $16.1^{\circ} \mathrm{C}$ (experiment 2) (www.wunderground.com). The optimum growth temperatures of the Ganoderma spp. tested are between 25 and $30^{\circ} \mathrm{C}$, although all four species grow between 15 and $35^{\circ} \mathrm{C}$ (Adaskaveg and Gilbertson 1986, 1989). Trees were irrigated daily in the summer months with drip irrigation for $45 \mathrm{~min}$ (approximately $400 \mathrm{ml} / \mathrm{min}$ ), and as needed in the dormant season with automated irrigation to maintain the health of the trees and regulate temperature.

To prepare inoculum, dikaryotic isolates were cultured onto MEA for 7 days and then inoculated into sterilized, hydrated rye grain in half-filled $237 \mathrm{ml}$ glass jars and incubated at $27^{\circ} \mathrm{C}$ until fully colonized (approximately 3 weeks). Commercially available birch dowels (Fungi Perfecti, Olympia, WA) $(0.8 \times 2.54 \mathrm{~cm})$ were soaked in distilled $\mathrm{H}_{2} \mathrm{O}$ for $24 \mathrm{~h}$ and then sterilized by autoclaving for $45 \mathrm{~min}$ in $237 \mathrm{ml}$ glass jars at $121^{\circ} \mathrm{C}$ at $103 \mathrm{kPa}$. Sterile wooden dowels were infested with grain inoculum of each respective isolate, and were incubated at $27^{\circ} \mathrm{C}$ for 6 weeks.

Trees were inoculated on 28 June 2016 (experiment 1) and 20 December 2016 (experiment 2) by drilling $2.54 \mathrm{~cm}$ into the lower bole of trees with a $0.8 \mathrm{~cm}$ diameter drill bit, and placing the infested or noninfested (mock inoculated control) dowels into this void. Two inoculation sites adjacent to each other were made in experiment 2. For palms, a $30 \mathrm{~cm}$ long, $0.8 \mathrm{~cm}$ diameter drill bit was used to drill through the boots (leaf scars) to a point below the primordial leaves of the meristem, where root initials were forming, then two infested dowels were placed in this void. For each experiment, dowels

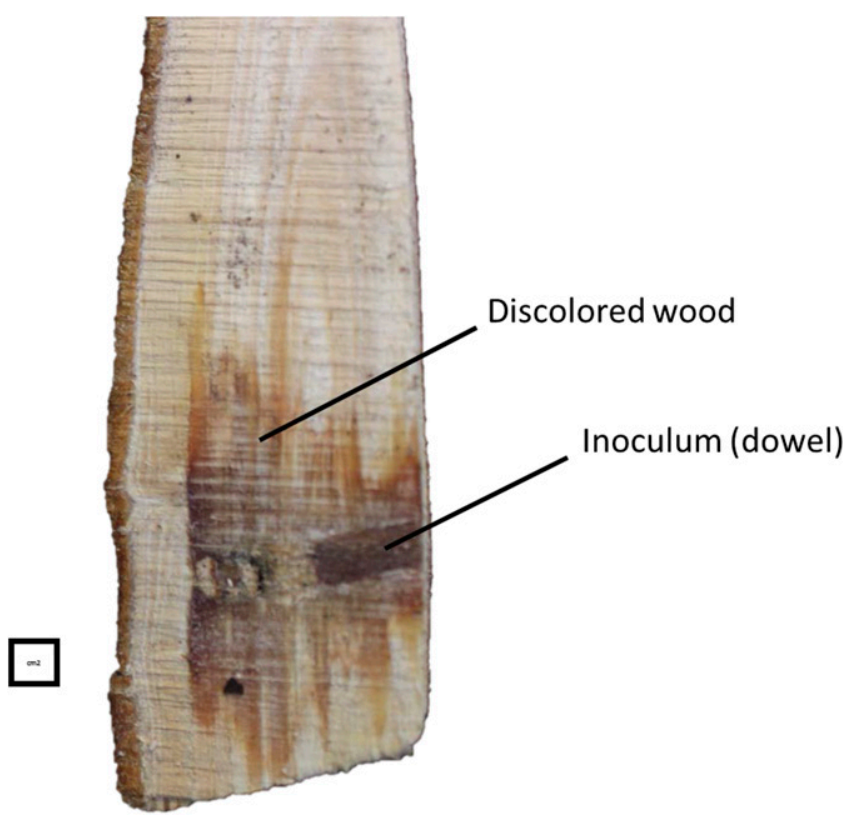

Fig. 1. Longitudinal cross section through inoculation site, showing where attempts to recover Ganoderma species were made (discolored wood and infested dowelinoculum). This sample (169) was from Pinus elliottii var. elliottii inoculated with $G$. meredithiae. The scale box outlined in black measures $1 \mathrm{~cm}^{2}$. infested with each species were plated on the day of inoculation on MEA to confirm viability. Paraffin wax was used to seal the inoculation sites to avoid contamination and drying out of inoculum.

Destructive harvest, disease assessment, and reisolations. Trees were monitored monthly for disease symptoms and destructively harvested and rated after approximately 12 (experiment 1 ) and 11 months (experiment 2 ) of incubation and destructively harvested on 5 July 2017 (experiment 1) and 8 November 2017 (experiment 2). Tree health ratings ( 1 to 3 ) were recorded, where 1 was healthy, 2 was symptomatic, and 3 was dead. Trees were cut below the inoculation site and sectioned into approximately $15 \mathrm{~cm}$ long sections. Longitudinal cuts were made through the inoculation point with a bandsaw. Each inoculation site on each tree was rated on a 1 to 4 wound response rating scale, where 1 was complete wound closure; 2 was response wood present, but wound not closed; 3 was no wound closure; and 4 was external decay cavity formed in the xylem outside the point of inoculation. In addition, photographs were taken for all longitudinal cross sections of the inoculation sites in order to measure surface area of internal xylem discoloration from the inoculation. Surface area measurements were made using the computer program Assess 2.0 (APS, St. Paul, MN). Finally, isolations were made from the inoculum (dowel) and discolored wood (Fig. 1) from each tree by taking five small sections $\left(<1 \mathrm{~mm}^{3}\right)$ from the respective locations, surface sterilizing them in $50 \%$ sodium hypochlorite solution for $30 \mathrm{~s}$, rinsing in sterile water, blotting dry, and plating them onto MEA amended with benomyl, streptomycin, and lactic acid as described previously. Subcultures of suspect Ganoderma isolations were made onto MEA, and identified using morphology. Pindo palms showed no exterior symptoms, and due to the difficulty of sectioning the young palms, they were not destructively harvested.

Statistical analyses. Since the tree health and average wound response rating data were not normally distributed, these data were analyzed using a one-way nonparametric Wilcoxon test, with means separation using Wilcoxon pairwise comparisons in JMP PRO v. 12. Data were analyzed independently for each experiment and tree species, with Ganoderma species or mock inoculated control as the independent variable and ratings as the dependent variable. To test for differences in surface area of discoloration with the different Ganoderma inoculations relative to the mock inoculated control, analysis of variance (ANOVA) and Dunnett's Means comparison test were calculated independently for each experiment and tree species in JMP PRO v. 12, with Ganoderma species or mock inoculated control as the independent variable and area of internal xylem discoloration as the dependent variable.

\section{Results}

Disease assessment, wound responses, and reisolations. No symptoms of disease, external lesions, or decay were observed at 11 or 12 months postinoculation on any tree species inoculated with any of the four Ganoderma species. Additionally, no symptoms were found on any of the mock inoculated controls. All trees were therefore given a tree health rating of one. However, in experiment 2, all $Q$. virginiana trees, both inoculated and mock-inoculated, died 3 months post inoculation. Presumably, death was due to the inoculation method, which girdled the cambium tissue. Because of this, live oak trees in experiment 2 were removed from the statistical analyses.

In experiment 1, all Ganoderma inoculations and mock inoculated controls on live oak, loblolly pine, and Shumard oak had an average wound response rating of one or two, meaning that the inoculation site had completely closed with response wood, or had some response wood present and were in the process of wound closing. Similarly, in experiment 2, loblolly pines and Shumard oaks inoculated with the four Ganoderma species and mock inoculated controls had an average wound response rating of one or two. In both experiments, there was no statistical difference $(P>0.05)$ in tree health rating or average wound response rating between trees inoculated with the Ganoderma species and mock inoculated controls (Table 2).

There were differences in extent of internal discoloration in some of the Ganoderma inoculations relative to the mock inoculated 
controls, although few were statistically significant $(P \leq 0.05)$. When compared with the control, all Ganoderma inoculations in experiment 1 had higher average internal discoloration of xylem, but the differences were only significant for inoculations with $G$. meredithiae $(P=0.05)$ and $G$. sessile $(P=0.02)$ on pine, and $G$. meredithiae on Shumard oak $(P=0.04)$ (Table 2$)$. In experiment 2 , there was no statistical difference in discolored area of the internal xylem tissues between the inoculations with four Ganoderma species and mock inoculated controls. In both experiments, live oak trees had the least amount of discolored area relative to the other trees, while Shumard oaks (experiment 1) and pine (experiment 2) had the most.

With the exception of trees inoculated with G. sessile, the inoculated Ganoderma species were not successfully reisolated from either the original inoculum (infested dowel) or the surrounding discolored wood (Table 3). In both experiments, G. sessile was isolated from the inoculum (infested dowel) and the discolored wood outside the inoculation site from both live oak and Shumard oak, but was only isolated from the infested dowel from the two pine species (Table 3).

\section{Discussion}

Throughout the course of both experiments, no external symptoms were observed across four tree species inoculated with any of four Ganoderma species, or in the mock inoculated controls. It is generally thought that Ganoderma butt or trunk rot requires wounded roots or trunk tissue as an infection court for successful infection by a Ganoderma species (Adaskaveg and Gilbertson 1987; Pirone 1957; Sinclair and Lyon 2005). Although trees were wounded in these experiments and inoculation methods were similar to other published experiments (Deflorio et al. 2008; Nicolotti et al. 2004), the four Ganoderma spp. tested were found to not be pathogens of sapwood in these young, actively growing trees with the inoculation method used. Furthermore, all Ganoderma and mock inoculated oaks

Table 2. Average total area of discolored wood and external wound response ratings for Pinus taeda, P. elliottii, Quercus shumardii, and Q. virginiana inoculated with four Ganoderma species

\begin{tabular}{|c|c|c|c|c|}
\hline \multirow[b]{2}{*}{ Inoculum } & \multicolumn{2}{|c|}{ Experiment 1} & \multicolumn{2}{|c|}{ Experiment 2} \\
\hline & Discolored area $\left(\mathrm{cm}^{2}\right)^{a}$ & Wound response ratingb & Discolored area $\left(\mathrm{cm}^{2}\right)$ & Wound response rating \\
\hline \multicolumn{5}{|l|}{ Quercus virginiana } \\
\hline Control & $4.8 \pm 1.1$ & 1 & $\mathrm{NA}^{\mathrm{c}}$ & NA \\
\hline Ganoderma curtisii & $6.1 \pm 1.1$ & 1 & NA & NA \\
\hline G. meredithiae & $6.9 \pm 1.0$ & 1 & NA & NA \\
\hline G. sessile & $6.9 \pm 2.6$ & 1 & NA & NA \\
\hline G. zonatum & $7.1 \pm 2.0$ & 1 & NA & NA \\
\hline \multicolumn{5}{|l|}{ Pinus sp. ${ }^{\mathrm{d}}$} \\
\hline Control & $6.1 \pm 1.4$ & 1 & $12.9 \pm 1.6$ & 2 \\
\hline G. curtisii & $9.4 \pm 2.2$ & 1 & $12.8 \pm 3.5$ & 2 \\
\hline G. meredithiae & $9.2 \pm 1.8^{* \mathrm{e}}$ & 1 & $19.1 \pm 7.4$ & 2 \\
\hline G. sessile & $9.7 \pm 2.1^{*}$ & 2 & $12.1 \pm 3.2$ & 2 \\
\hline G. zonatum & $8.6 \pm 1.5$ & 1 & $13.5 \pm 3.5$ & 2 \\
\hline \multicolumn{5}{|l|}{ Quercus shumardii } \\
\hline Control & $4.8 \pm 0.9$ & 1 & $8.0 \pm 1.8$ & 1 \\
\hline G. curtisii & $10.2 \pm 3.1$ & 1 & $10.2 \pm 1.4$ & 1 \\
\hline G. meredithiae & $11.1 \pm 4.5^{*}$ & 1 & $11.8 \pm 4.5$ & 1 \\
\hline G. sessile & $10.1 \pm 3.8$ & 1 & $10.1 \pm 1.1$ & 2 \\
\hline G. zonatum & $10.1 \pm 3.8$ & 1 & $9.4 \pm 2.1$ & 1 \\
\hline
\end{tabular}

${ }^{a}$ Each cell represents averages of replicates where $n=5$. Values represent the average discolored area \pm the standard deviation.

${ }^{\mathrm{b}}$ Values represent the average wound response rating rounded to the nearest rating.

c Not analyzed, due to death from inoculation method because of death of hosts due to inoculation method.

d Pinus taeda in experiment 1 , and P. elliottii var. elliottii in experiment 2.

e Values with * are statistically significant $(P \leq 0.05)$ with Dunnet's test relative to the control.

Table 3. Frequency of recovering Ganoderma species from inoculum (infested dowel) and discolored wood of trees 11 to 12 months post inoculation

\begin{tabular}{|c|c|c|c|c|}
\hline & \multicolumn{2}{|c|}{ Experiment 1} & \multicolumn{2}{|c|}{ Experiment 2} \\
\hline & Inoculum & $\overline{\text { Discolored wood }}$ & Inoculum & Discolored wood \\
\hline Quercus virginiana inoculum control & $\mathrm{a}^{\mathrm{a}}$ & - & - & - \\
\hline G. curtisii & - & - & - & - \\
\hline G. meredithiae & - & - & - & - \\
\hline G. sessile & $++^{\mathrm{b}}$ & + & ++++ & ++++ \\
\hline G. zonatum & - & - & - & - \\
\hline Pinus sp..$^{\mathrm{c}}$ inoculum control & - & - & - & - \\
\hline G. curtisii & - & - & - & - \\
\hline G. meredithiae & - & - & - & - \\
\hline G. sessile & ++ & - & +++ & - \\
\hline G. zonatum & - & - & - & - \\
\hline Quercus shumardii inoculum control & - & - & - & - \\
\hline G. curtisii & - & - & - & - \\
\hline G. meredithiae & - & - & - & - \\
\hline G. sessile & ++++ & ++++ & ++ & +++ \\
\hline G. zonatum & - & - & - & - \\
\hline
\end{tabular}

a - indicates that reisolation was unsuccessful.

${ }^{\mathrm{b}}+$ indicates successful reisolation, where each + indicates success in one replicate, and +++++ indicates success for five replicates per Ganoderma species/host tree combination.

${ }^{c}$ Pinus taeda in experiment 1 , and P. elliottii var. elliottii in experiment 2. 
and pines had wounds that were completely or partially closed over, which suggests that active compartmentalization was occurring.

The internal xylem discoloration observed across all tree species and inocula appeared to be the result of wounding, and not Ganoderma infection. Trees respond to wounding of the sapwood by producing antimicrobial compounds that often stain the wood and function by deterring decay organisms from establishing (Deflorio et al. 2008; Scheffer and Morrell 1998; Shigo 1985). Antimicrobial chemicals are also naturally produced in sapwood when it converts to heartwood (Schwarze et al. 2000). In addition to plant defense chemicals discoloring wood, bacteria and wood staining fungi are often prevalent in wounded sapwood tissues (Scheffer and Cowling 1966).

Previous studies have shown Ganoderma species to be poor competitors in the soil (Bakshi et al. 1976; Rees et al. 2007). In addition, for successful infection, Ganoderma propagules have to be in contact with or in close proximity ( 1 to $2 \mathrm{~cm}$ ) to the infection court (Adaskaveg and Gilbertson 1987; Bakshi et al. 1976; Rees et al. 2007). Although our inoculations were placed into the infection court (i.e., trunk wound), no visible decay was observed. The internal xylem discoloration, which was presumably produced by antimicrobial plant defense chemicals (e.g., phenolics) or the colonization of wood staining microbes, could help explain the unsuccessful infections with G. curtisii, G. meredithiae, and G. zonatum and the lack of decay with all Ganoderma species in the oak and pine trees. Plant defense chemicals could have made the sapwood uninhabitable, while wood staining microbes could have outcompeted the Ganoderma species. It is also possible that the inoculation method was not the appropriate method and it failed for other reasons. This is based on the unsuccessful reisolation attempts with G. curtisii, G. meredithiae, and $G$. zonatum from the infested dowels after 11 to 12 months of incubation in the infection court.

We chose to wound-inoculate on lower trunks, because i) earlier studies had successfully used this method, and ii) it has long been accepted that lower trunk injuries, such as lawn mower injuries, are a prime entry point for Ganoderma and other wood decay fungi. However, we did not observe disease development with this method, and in fact were unable to recover the pathogen in most cases. There is precedent in the literature suggesting that fresh, actively growing sapwood is not conducive for pathogen establishment (Blanchette 1991; Boddy and Rayner 1983). Sapwood has a higher moisture content and lower oxygen content than heartwood, which is not optimal for mycelial growth of many wood decay fungi (Boddy 1983; Boddy and Rayner 1983). In a laboratory decay study, Lentinus edodes and Hypoxylon truncatum decayed oak and beech wood better under moderate moisture conditions in contrast to low and high moisture conditions (Abe 1989). Similarly, there is a positive correlation of lignin degradation and high oxygen contents (Blanchette 1991). Given that sapwood is high in moisture and low in oxygen, and some decay fungi seem to be negatively affected by low oxygen and high moisture conditions, it is not surprising that infections in functional sapwood (living) by decay fungi is unlikely (Boddy and Rayner 1983). Furthermore, sapwood consists of living cells that have an active response to wounding, fungal infections, and beetle infestations, and it is possible that active compartmentalization and plant defense chemicals deterred the fungi from establishing (Blanchette and Biggs 1992).

In a previous inoculation experiment, the reisolation of G. lucidum sensu lato was successful from heartwood and pith tissues of inoculated field-grown grapevines, but reisolation was not successful from sapwood tissues (Adaskaveg and Gilbertson 1987). Although healthy sapwood may be a non-preferential tissue as an infection court, as shown previously (Adaskaveg and Gilbertson 1987; Boddy and Rayner 1983), dead sapwood can be rapidly decayed by these four Ganoderma species (Loyd et al. 2018). Freshly wounded sapwood may also be a non-preferential infection court, but $G$. sessile was able to infect the sapwood of both oak species. In fact, $G$. sessile was the only species consistently isolated from the sapwood, which we suspect was because it constitutively produces chlamydospores, which aid in survival. These propagules, we suspect, allow G. sessile to persist in healthy trees, and lay dormant as an opportunistic saprophyte. We speculate that this latent opportunistic saprophytic phase persists as an endophyte. This endophytic life stage, where the Ganoderma species is living in wood, but not actively decaying wood, seems to be an understudied, yet important part of the Ganoderma life cycle (Martin et al. 2015).

Trees in the landscape often experience mechanical wounding from machinery such as lawn mowers and weed eaters, and presumably these wounded tissues can become infection courts for decay fungi, such as species of Ganoderma. However, these data suggest that there is a low likelihood of infection immediately following wounding of trees that only possess sapwood or wounds of larger trees that only are in sapwood and don't reach heartwood. The failure of our isolates to establish in fresh trunks raises questions about the entry of wood rot pathogens in trunk injuries. It is likely that such wounds are not immediately conducive to pathogen entry and establishment, but become more so as the wounds age and sapwood within them dies. These data suggest that some factors not present in our study, such as stress, age of tree, or wood type (sapwood versus heartwood) could play a role in enabling pathogenicity. More research is needed to elucidate how and when Ganoderma infections establish in wounded trunks and result in decay.

Although others have been successful with trunk inoculations, it is likely that we would have seen more success with root inoculations, given that our trees were young and lacked heartwood. For example, Adaskaveg and Gilbertson (1987) inoculated grape roots with G. lucidum sensu lato, and observed that the fungus infected the roots, and decay progressed from roots to the pith and inner discolored wood of the grape vine, only entering the sapwood in later stages of decay. Similarly, Toole (1966) inoculated roots of young green ash (Fraxinus pennsylvanica), sweetgum (Liquidambar styraciflua), and mimosa (Albizia julibrissin) trees with wood block inoculum of G. lucidum sensu lato (syn.=P. lucidus sensu lato), and had successful infections of all trees and mortality of sweetgum and mimosa trees.

Overall, the four Ganoderma species were not sapwood pathogens of the hosts tested, immediately following wounding of the lower trunk tissue. However, the type of infection court, age of tree, and environmental conditions could have played a role in the lack of infections. Inoculations using sealed inoculation sites on wounded roots in young trees and mature trees with heartwood should be completed to fully evaluate the pathogenicity of these Ganoderma species on these hosts. The role of tree stress during inoculation by Ganoderma species also deserves additional study.

\section{Acknowledgments}

We would like to thank Claudia Paez, Matthew Eicholtz, and Lanette Sobel for their help in experimental setup.

\section{Literature Cited}

Abe, Y. 1989. Effect of moisture on the colonization by Lentinus edodes and Hypoxylon truncatum in wood. For. Pathol. 19:423-434.

Adaskaveg, J., Blanchette, R., and Gilbertson, R. 1991. Decay of date palm wood by white-rot and brown-rot fungi. Can. J. Bot. 69:615-629.

Adaskaveg, J., and Gilbertson, R. 1987. Infection and colonization of grapevines by Ganoderma lucidum. Plant Dis. 71:251-253.

Adaskaveg, J., and Gilbertson, R. 1988. Ganoderma meredithae, a new species on pines in the southeastern United States. Mycotaxon 31:251-257.

Adaskaveg, J., and Gilbertson, R. 1989. Cultural studies of four North American species in the Ganoderma lucidum complex with comparisons to G. lucidum and G. tsugae. Mycol. Res. 92:182-191.

Adaskaveg, J., Miller, R., and Gilbertson, R. 1993. Wood decay, lignicolous fungi, and decline of peach trees in South Carolina. Plant Dis. 77:707-711.

Adaskaveg, J. E., and Gilbertson, R. L. 1986. Cultural studies and genetics of sexuality of Ganoderma lucidum and G. tsugae in relation to the taxonomy of the G. lucidum complex. Mycologia 78:694-705.

Agrios, G. N. 2005. Plant Pathology. Elsevier Science, San Diego, CA.

Baietto, M., and Wilson, D. A. 2010. Relative in vitro wood decay resistance of sapwood from landscape trees of southern temperate regions. HortScience 45:401-408.

Bakshi, B., Reddy, M., and Singh, S. 1976. Ganoderma root rot mortality in khair (Acacia catechu Willd.) in reforested stands. For. Pathol. 6:30-38.

Bhadra, M. 2015. Ganoderma association with the mortality of Acacia auriculiformis, susceptibility to different hosts and its controls. J. Plant Pathol. Microbiol. 5: 238 
Blanchette, R. A. 1984. Screening wood decayed by white rot fungi for preferential lignin degradation. Appl. Environ. Microbiol. 48:647-653.

Blanchette, R. A. 1991. Delignification by wood-decay fungi. Annu. Rev. Phytopathol. 29:381-403.

Blanchette, R. A., and Biggs, A. R. 1992. Defense mechanisms of woody plants against fungi. Springer-Verlag, Berlin.

Boddy, L. 1983. Effect of temperature and water potential on growth rate of woodrotting basidiomycetes. Trans. Br. Mycol. Soc. 80:141-149.

Boddy, L., and Rayner, A. 1983. Origins of decay in living deciduous trees: the role of moisture content and a re-appraisal of the expanded concept of tree decay. New Phytol. 94:623-641.

Coetzee, M., Marincowitz, S., Muthelo, V. G., and Wingfield, M. J. 2015. Ganoderma species, including new taxa associated with root rot of the iconic Jacaranda mimosifolia in Pretoria, south Africa. IMA Fungus 6:249-256.

Deflorio, G., Johnson, C., Fink, S., and Schwarze, F. W. M. R. 2008. Decay development in living sapwood of coniferous and deciduous trees inoculated with six wood decay fungi. For. Ecol. Manage. 255:2373-2383.

Elliott, M., and Broschat, T. 2001. Observations and pathogenicity experiments on Ganoderma zonatum in Florida. Palms 45:62-73.

Elliott, M. L., and Broschat, T. K. 2000. Ganoderma Butt Rot of Palms. University of Florida IFAS Extension Bulletin 5.

Elshafie, A., Al-Bahry, S., El-Nagerabi, S., and Al-Kindi, K. 2013. New record of Ganoderma colossum associated with Sclerocarya birrea dieback. Australas. Plant Dis. Notes 8:85-87.

Fernando, K. 2008. The host preference of a Ganoderma lucidum strain for three tree species of Fabaceae family; Cassia nodosa, Cassia fistula and Delonix regia. J. Natl. Sci. Found. Sri Lanka 36:323-326.

Franceschi, V. R., Krokene, P., Christiansen, E., and Krekling, T. 2005. Anatomical and chemical defenses of conifer bark against bark beetles and other pests. New Phytol. 167:353-376.

Gardes, M., and Bruns, T. D. 1993. ITS primers with enhanced specificity for basidiomycetes-application to the identification of mycorrhizae and rusts. Mol. Ecol. 2:113-118.

Gilbertson, R., and Ryvarden, L. 1986. North American Polypores. Volume 1: Abortiporus to Lindteria. Fungiflora AS, Oslo, Norway.

Glen, M., Bougher, N. L., Francis, A. A., Nigg, S. Q., Lee, S. S., Irianto, R., Barry, K. M., Beadle, C. L., and Mohammed, C. L. 2009. Ganoderma and Amauroderma species associated with root-rot disease of Acacia mangium plantation trees in Indonesia and Malaysia. Australas. Plant Pathol. 38:345-356.

Hennicke, F., Cheikh-Ali, Z., Liebisch, T., Maciá-Vicente, J. G., Bode, H. B., and Piepenbring, M. 2016. Distinguishing commercially grown Ganoderma lucidum from Ganoderma lingzhi from Europe and East Asia on the basis of morphology, molecular phylogeny, and triterpenic acid profiles. Phytochemistry 127:29-37.

Hidayati, N., Glen, M., Nurrohmah, S., Rimbawanto, A., and Mohammed, C. 2014. Ganoderma steyaertanum as a root-rot pathogen of forest trees. For. Pathol. 44:460-471.

Hong, S. G., and Jung, H. S. 2004. Phylogenetic analysis of Ganoderma based on nearly complete mitochondrial small-subunit ribosomal DNA sequences. Mycologia 96:742-755.

Jorgensen, E. 1961. The formation of pinosylvin and its monomethyl ether in the sapwood of Pinus resinosa Ait. Can. J. Bot. 39:1765-1772.

Loyd, A. L., Held, B. W., Linder, E. R., Smith, J. A., and Blanchette, R. A. 2018. Elucidating wood decomposition by four species of Ganoderma from the United States. Fungal Biol. 122:254-263.
Mahmood, T. 1970. Ganoderma lucidum: a virulent incitant of basal stem rot, a malady of hardwoods in West Pakistan. Plant Dis. Rep. 55:1130-1131.

Martin, R., Gazis, R., Skaltsas, D., Chaverri, P., and Hibbett, D. 2015. Unexpected diversity of basidiomycetous endophytes in sapwood and leaves of Hevea. Mycologia 107:284-297.

Marx, D. H., and Daniel, W. J. 1976. Maintaining cultures of ectomycorrhizal and plant pathogenic fungi in sterile water cold storage. Can. J. Microbiol. 22: 338-341.

Moncalvo, J.-M., Wang, H.-F., and Hseu, R.-S. 1995. Gene phylogeny of the Ganoderma lucidum complex based on ribosomal DNA sequences. Comparison with traditional taxonomic characters. Mycol. Res. 99:1489-1499.

Nicolotti, G., Gonthier, P., and Giordano, L. 2004. An experimental study on the survival and infectivity of some root and butt rot fungi in urban environment. http://www.isaitalia.org/images/stories/documenti/Torino-2008/Nicolotti_G._ Gonthier_P._Giordano_L.pdf

Parfitt, D., Hunt, J., Dockrell, D., Rogers, H. J., and Boddy, L. 2010. Do all trees carry the seeds of their own destruction? PCR reveals numerous wood decay fungi latently present in sapwood of a wide range of angiosperm trees. Fungal Ecol. 3:338-346.

Pirone, P. P. 1957. Ganoderma lucidum, a parasite of shade trees. Bull. Torrey Bot. Club 84:424-428

Rees, R., Flood, J., Hasan, Y., and Cooper, R. M. 2007. Effects of inoculum potential, shading and soil temperature on root infection of oil palm seedlings by the basal stem rot pathogen Ganoderma boninense. Plant Pathol. 56: 862-870.

Scheffer, T. C., and Cowling, E. B. 1966. Natural resistance of wood to microbial deterioration. Annu. Rev. Phytopathol. 4:147-168

Scheffer, T. C., and Morrell, J. J. 1998. Natural durability of wood: A worldwide checklist of species. Technical Report, College of Forestry, Forest Research Laboratory, Oregon State University, Corvallis, OR

Schwarze, F., and Ferner, D. 2003. Ganoderma on trees-differentiation of species and studies of invasiveness. Arboric. J. 27:59-77.

Schwarze, F. W., Engels, J., and Mattheck, C. 2000. Fungal strategies of wood decay in trees. Springer-Verlag, Berlin.

Shigo, A. L. 1985. Compartmentalization of decay in trees. Sci. Am. 252:96-103.

Shigo, A. L., and Hillis, W. 1973. Heartwood, discolored wood, and microorganisms in living trees. Annu. Rev. Phytopathol. 11:197-222.

Sinclair, W. A., and Lyon, H. H. 2005. Diseases of trees and shrubs. Comstock Publishing Associates, Ithaca, NY.

Song, Z., Kennedy, P. G., Liew, F. J., and Schilling, J. S. 2017. Fungal endophytes as priority colonizers initiating wood decomposition. Funct. Ecol. 31:407-418.

Toole, E. 1966. Root rot caused by Polyporus lucidus. Plant Dis. Rep. 50: 945-946.

Wang, X. C., Xi, R. J., Li, Y., Wang, D. M., and Yao, Y. J. 2012. The species identity of the widely cultivated Ganoderma, 'G. lucidum' (Ling-zhi), in China. PLoS One 7:e40857.

White, T. J., Bruns, T., Lee, S., and Taylor, J. 1990. Amplification and direct sequencing of fungal ribosomal RNA genes for phylogenetics. Pages 315-322 in: PCR Protocols: A Guide to Methods and Applications. Academic Press, San Diego, CA

Zhou, L.-W., Cao, Y., Wu, S.-H., Vlasák, J., Li, D.-W., Li, M.-J., and Dai, Y.-C. 2015. Global diversity of the Ganoderma lucidum complex (Ganodermataceae, Polyporales) inferred from morphology and multilocus phylogeny. Phytochemistry 114:7-15. 